\title{
Transcriptomic responses to heat stress and bleaching in the elkhorn coral Acropora palmata
}

\author{
Michael K. DeSalvo ${ }^{1}$, Shinichi Sunagawa ${ }^{1}$, Christian R. Voolstra ${ }^{1,2}$, Mónica Medina ${ }^{1, *}$ \\ ${ }^{1}$ School of Natural Sciences, University of California Merced, Merced, California 95343, USA \\ ${ }^{2}$ Red Sea Research Center, King Abdullah University of Science and Technology (KAUST), Thuwal, Saudi Arabia
}

\begin{abstract}
The emergence of genomic tools for reef-building corals and symbiotic anemones comes at a time when alarming losses in coral cover are being observed worldwide. These tools hold great promise in elucidating novel and unforeseen cellular processes underlying the successful mutualism between corals and their dinoflagellate endosymbionts Symbiodinium spp. Since thermal stress triggers a breakdown in the symbiosis (coral bleaching), measuring the transcriptomic response to thermal stress-induced bleaching offers an extraordinary view of cellular processes that are specific to coral-algal symbioses. In the present study, we utilized a cDNA microarray containing 2059 genes of the threatened Caribbean elkhorn coral Acropora palmata to identify genes that are differentially expressed upon thermal stress. Fragments from replicate colonies were exposed to elevated temperature for $2 \mathrm{~d}$, and samples were frozen for microarray analysis after 24 and $48 \mathrm{~h}$. Totals of 204 and 104 genes were differentially expressed in samples that were collected 1 and $2 \mathrm{~d}$ after thermal stress, respectively. Analysis of the differentially expressed genes indicates a cellular stress response in A. palmata involving (1) growth arrest, (2) chaperone activity, (3) nucleic acid stabilization and repair, and (4) removal of damaged macromolecules. Other differentially expressed processes include sensory perception, metabolite transfer between host and endosymbiont, nitric oxide signaling, and modifications to the actin cytoskeleton and extracellular matrix. The results are compared with those from a previous coral microarray study of thermal stress in Montastraea faveolata, and point to an overall evolutionary conserved bleaching response in scleractinian corals.
\end{abstract}

KEY WORDS: Coral bleaching $\cdot$ Microarray $\cdot$ Transcriptomics $\cdot$ Heat stress

\section{INTRODUCTION}

Coral reefs are the most diverse marine ecosystem, yet numerous anthropogenic stressors currently threaten their vitality (Hoegh-Guldberg et al. 2007). Understanding how scleractinian corals and their associated microbes (especially the photosynthetic dinoflagellates of the genus Symbiodinium) will respond to future stress requires knowledge of the molecular and cellular bases of the symbiosis itself and the events that lead to the collapse of symbiosis (i.e. bleaching). Genomic-scale approaches can help attain a new level of understanding, which in turn can propel the study of coral symbiosis into the realm of systems biology, whereby predictive mathematical models can more efficiently extract information from genomic studies.
Initial ventures into the field of coral functional genomics have focused on environmental stress in natural populations of Montastraea faveolata (Edge et al. 2005, 2008, Morgan et al. 2005), thermal stress and bleaching in $M$. faveolata (DeSalvo et al. 2008), development in Acropora millepora (Grasso et al. 2008), and the transcriptomic response to symbiosis establishment in $M$. faveolata and Acropora palmata (Voolstra et al. 2009). Also relevant to this burgeoning discipline are microarray studies on the temperate symbiotic anemone Anthopleura elegantissima. Rodriguez-Lanetty et al. (2006) measured transcriptomic differences between symbiotic and aposymbiotic anemones, and Richier et al. (2008) quantified gene expression following UV and thermal stress. These initial studies have provided a wealth of information on the molecular basis of 
cnidarian-algal symbioses and the transcriptomic response to thermal stress and bleaching. Not only have studies on stress corroborated early findings (e.g. the involvement of oxidative stress and apoptosis), but they have also revealed new aspects of cnidarian physiology (e.g. the involvement of cytoskeletal remodeling, ribosomal protein transcript down-regulation, and $\mathrm{Ca}^{2+}$ homeostasis disruption) that are relevant to thermal stress and bleaching (DeSalvo et al. 2008, Richier et al. 2008).

Perhaps the most exciting results from early transcriptomic studies on cnidarian stress are transcripts encoding cell signaling molecules, transcription factors, transport proteins, and extracellular matrix proteins. These newly identified focal molecules are prime candidates for future inquiries since the precise cellular signaling mechanisms of bleaching are still unknown. For example, the following candidates overlap between the differentially expressed genes reported by DeSalvo et al. (2008) and those reported by Richier et al. (2008): CCAAT/enhancer binding protein transcription factors, tropomyosin (an actin-binding cytoskeletal protein), sec61 (an endoplasmic reticulum protein translocation channel), and tissue factor pathway inhibitor (a member of the BPTI/Kunitz family of serine protease inhibitors).

Studying bleaching mechanisms in zooxanthellate cnidarians such as Anthopleura elegantissima, Aiptasia pallida, and scleractinian corals offers the advantage of taking an evolutionary comparative approach. The aforementioned anemones are highly amenable to laboratory culture and manipulation, and thus hold much promise in the study of cnidarian bleaching mechanisms (Weis et al. 2008). In the interest of directly studying bleaching in reef-building corals, we have taken a comparative approach by investigating the transcriptomic response to bleaching in the robust clade coral Montastraea faveolata (DeSalvo et al. 2008) and the complex clade coral Acropora palmata (present study). This approach enables us to examine whether coral species separated by 240 to 288 million years (Medina et al. 2006) respond similarly (at transcriptomic and organismal levels) to thermal stress and bleaching. Despite known differences in the bleaching susceptibilities of branching versus encrusting corals (e.g. Loya et al. 2001), we hypothesized that the overall transcriptomic responses to bleaching are consistent in these divergent species. A similar approach used by Voolstra et al. (2009) found that larvae of Acropora palmata and $M$. faveolata responded similarly to infection by competent and incompetent strains of Symbiodinium spp.

In the present study, we report a microarray-based experiment on thermal stress and bleaching in Acropora palmata. The experiment was performed concur- rently with our previously published study on thermal stress and bleaching in Montastraea faveolata (DeSalvo et al. 2008). While A. palmata bleached faster at the same temperature increase, the transcriptomic response was very similar to that observed in $M$. faveolata. Specific similarities and differences are discussed in-depth, and the functional annotations of differentially expressed genes are discussed in the context of previous findings, thus extending the current view of both the cellular stress response and the cellular mechanisms underlying coral bleaching.

\section{MATERIALS AND METHODS}

Field experiment. The field experiment was performed at the Smithsonian Tropical Research Institute's Bocas del Toro field station in Panamá during September and October 2006. Four colonies of Acropora palmata were sampled from 2 separate reefs that were $21 \mathrm{~km}$ apart ( 2 colonies from Isla Solarte at $9^{\circ} 19^{\prime} 56.78^{\prime \prime} \mathrm{N}$ and $82^{\circ} 12^{\prime} 54.65^{\prime \prime} \mathrm{W}$, and 2 colonies from Cayos Zapatillas at $9^{\circ} 15^{\prime} 08.79^{\prime \prime} \mathrm{N}$ and $82^{\circ} 02^{\prime} 24.63^{\prime \prime} \mathrm{W}$ ). Each colony was broken into 6 fragments using a hammer and chisel. For each colony, 3 fragments were placed in a control aquarium, and 3 fragments were placed in an experimental aquarium that was fitted with two $200 \mathrm{~W}$ aquarium heaters (each colony was represented by a pair of $75 \mathrm{l}$ aquaria). The 4 control and 4 experimental aquaria were each placed in large fiberglass ponds with continuous water flow to buffer ambient temperature fluctuations.

All aquaria were exposed to shaded ambient light, and each aquarium was a closed system (but contained a pump to generate continuous water flow). Fragments were kept at a depth of $\sim 25 \mathrm{~cm}$. HOBO pendant temperature/light data loggers (Onset, UA-002-64) recorded temperature and light data every $3 \mathrm{~min}$. These data loggers are not designed to measure photosynthetically active radiation; therefore, relative light levels in the aquaria are reported as percentages of the average 10:00 to $14: 00 \mathrm{~h}$ light intensity that was measured on a reef $\sim 4 \mathrm{~m}$ deep in Bocas del Toro $\left(9^{\circ} 22^{\prime} 68.4^{\prime \prime} \mathrm{N}\right.$, $\left.82^{\circ} 18^{\prime} 24.6^{\prime \prime} \mathrm{W}\right)$ during September and October 2007. Light intensity differed slightly among the 4 aquaria that were fitted with HOBOs (control aquarium 1: $43 \%$; control aquarium 2; $46 \%$; heated aquarium 1: $35 \%$; and heated aquarium 2: $34 \%$ of reef light).

After a $4 \mathrm{~d}$ acclimation period at the natural temperature of the seawater system (mean temperature: $30.29 \pm 0.07^{\circ} \mathrm{C}$ ), a fragment from each control and experimental aquarium was sampled (t0C and $\mathrm{t} 0 \mathrm{H}$ ). After time 0 sampling, the heaters in each of the experimental aquaria were turned on. The temperatures of the experimental aquaria increased to $\sim 32^{\circ} \mathrm{C}$ over $3 \mathrm{~h}$. The mean temperature of the control aquaria during the 
entire experiment was $29.74 \pm 0.03^{\circ} \mathrm{C}$, while the mean temperature of the heated aquaria was $32.72 \pm 0.32^{\circ} \mathrm{C}$. Control and experimental fragments were sampled again $1 \mathrm{~d}(1 \mathrm{dC}$ and $1 \mathrm{dH})$ and $2 \mathrm{~d}(2 \mathrm{dC}$ and $2 \mathrm{dH})$ after the heaters were turned on. Heated fragments from 1 of the colonies (colony 3) showed extreme bleaching after $1 \mathrm{~d}$ of thermal stress. The remaining fragment of colony 3 was removed at this time to avoid fouling of the water. Thus, there were 4 replicates for $\mathrm{t} 0 \mathrm{C}, \mathrm{t} 0 \mathrm{H}$, $1 \mathrm{dC}$, and $1 \mathrm{dH}$, and 3 replicates for $2 \mathrm{dC}$ and $2 \mathrm{dH}$. All samples were taken at night and frozen in liquid nitrogen. Immediately prior to freezing, a polyp-size tissue scraping $\left(\sim 12.6 \mathrm{~mm}^{2}\right)$ was preserved in $1 \mathrm{ml}$ of $3.7 \%$ formaldehyde for Symbiodinium cell density counts.

Symbiodinium cell counts and 18S rRNA gene restriction fragment length polymorphism (RFLP) analysis. The formaldehyde-fixed tissue scrapings were homogenized by maceration with a dissecting needle and vortexed. Cell counts were performed using a hemocytometer. Eight replicate cell counts were averaged for each coral genotype at each time point. After testing for normality and equal variances within time points, significance of differences between time points was assessed using 1-way ANOVA and pairwise post-hoc testing via the Fisher LSD method. All statistical tests were performed using SigmaStat 3.11 .

Genomic DNA was isolated from frozen coral powder (see next section) using the PowerPlant DNA isolation kit (MoBio). The Symbiodinium 18S ribosomal RNA gene was amplified from all samples using the primers ss5 and ss3Z (Rowan \& Powers 1991). The resulting $1.5 \mathrm{~kb}$ fragment was digested with TaqI restriction enzyme, and the resulting fragments were compared with Symbiodinium clade standards (Rowan \& Knowlton 1995).

RNA extraction and microarray hybridization. Total RNA from all frozen coral fragments was isolated using QIAzol lysis reagent (Qiagen). Coral tissue was chiseled off each coral fragment and homogenized using a pre-chilled mortar and pestle (this method did not efficiently lyse endosymbiont cells). The frozen powder was transferred directly to QIAzol. Three chloroform extractions were performed, followed by isopropanol precipitation and 3 washes in $70 \%$ ethanol. RNA pellets were re-dissolved in nuclease-free water and cleaned with RNeasy mini columns (Qiagen). RNA quantity and integrity were assessed with a NanoDrop ND-1000 spectrophotometer and an Agilent 2100 Bioanalyzer, respectively.

The microarray used in this study consisted of 2059 PCR-amplified cDNAs (spotted in duplicate) that were chosen from coral host-specific cDNA libraries described by Schwarz et al. (2008). Sequences were annotated via comparison with the SwissProt database using the BLAST algorithm and an E-value cutoff of $10^{-5}$ (the significance of a sequence match increases as the E-value approaches 0). Microarray post-processing and hybridization protocols followed previously published methods (DeSalvo et al. 2008), with a few slight changes. Briefly, $1 \mu \mathrm{g}$ of total RNA was amplified using the MessageAmp II aRNA kit (Ambion), and $3 \mu \mathrm{g}$ of aRNA per sample were primed with $10 \mu \mathrm{g}$ random nonamer for $10 \mathrm{~min}$ at $70^{\circ} \mathrm{C}$. Reverse transcription (RT) lasted for $2 \mathrm{~h}$ at $50^{\circ} \mathrm{C}$ using a master mix containing a 4:1 ratio of aminoallyl-dUTP to TTP and SuperScript III reverse transcriptase (Invitrogen). Following RT, single-stranded RNA was hydrolyzed by incubating the RT reactions in $10 \mu \mathrm{l}$ of $0.5 \mathrm{M}$ EDTA and $10 \mu \mathrm{l}$ of $1 \mathrm{M}$ $\mathrm{NaOH}$ for $15 \mathrm{~min}$ at $65^{\circ} \mathrm{C}$. After hydrolysis, RT reactions were cleaned using MinElute reaction cleanup columns (Qiagen). Cy3 and Cy5 dyes (GE Healthcare) were dissolved in $18 \mu \mathrm{l}$ of DMSO, and the coupling reactions lasted for $1 \mathrm{~h}$ at room temperature in the dark. Dye-coupled cDNAs were cleaned (MinElute), and Cy3- and Cy5-labeled cDNAs were mixed together in a hybridization buffer containing $0.25 \%$ sodium dodecyl sulphate (SDS), 25 mM HEPES, and $3 \times$ saline sodium citrate (SSC). The hybridization mixtures were boiled for 2 min at $99^{\circ} \mathrm{C}$, and then allowed to cool at room temperature for $5 \mathrm{~min}$. The cooled hybridization mixtures were pipetted under an mSeries Lifterslip (Erie Scientific), and hybridization took place in custom-fabricated hybridization chambers overnight at $63^{\circ} \mathrm{C}$. Microarrays were washed twice in $0.6 \times \mathrm{SSC}$ and $0.01 \% \mathrm{SDS}$, followed by a rinse in $0.06 \times \mathrm{SSC}$ and drying via centrifugation.

Microarray data analysis. Slides were immediately scanned using an Axon 4000B scanner (Molecular Devices) where care was taken to balance photomultiplier tube (PMT) settings. Gridding was performed using GenePix Pro 6.0. TIGR Express Converter was used to convert GenePix results files into .mev files for input into TIGR MIDAS 2.19 (Saeed et al. 2003). Data for a particular spot were discarded according to the stringent 1 bad channel policy. Additional data were discarded if spots had been flagged during gridding in GenePix, and if the intensity in either channel was $<30000$ units. After filtering, background-subtracted median intensity values were LOWESS normalized, and in-slide duplicates were averaged. Both PMT balancing and LOWESS normalization equalize for differing amounts of host RNA input (a potential issue when processing tissue where endosymbiont densities can vary). Microarray hybridization data (both raw and normalized) were deposited in GEO with the series record number GSE16151.

We employed a reference design where all control and heat-stressed samples (labeled with Cy5) were compared to a pooled reference aRNA sample (labeled 
with Cy3) composed of aRNA from the 4 t0C fragments. Since all RNA samples were compared to the reference sample, direct comparisons of gene expression across all time points and conditions can be performed. Furthermore, dye swapping is not needed in a reference design since all samples contain the same dye bias.

Genes were included in statistical analyses only if there were data for 3 out of 4 replicates for t0C, t0H, $1 \mathrm{dC}$, and $1 \mathrm{dH}$, and 2 out of 3 replicates for $2 \mathrm{dC}$ and $2 \mathrm{dH}$. This left 1697 genes for statistical analyses of gene expression. Missing values were imputed using PAMR (Tibshirani et al. 2002). The ratio between the fluorescence intensity of the 2 channels was then used as input for BAGEL (Bayesian Analysis of Gene Expression Levels) (Townsend \& Hartl 2002). The BAGEL software uses Bayesian probability to infer a relative expression level for each gene and statistical significance of differentially expressed genes. BAGEL computes an estimated mean and $95 \%$ credible interval of the relative level of expression for each gene in each treatment and time point (i.e. $\mathrm{t} 0 \mathrm{C}, \mathrm{t} 0 \mathrm{H}, 1 \mathrm{dC}, 1 \mathrm{dH}, 2 \mathrm{dC}$, and $2 \mathrm{dH}$ ). We used the conservative gene-by-gene criterion of nonoverlapping $95 \%$ credible intervals to regard a gene as significantly differentially expressed. Genes that were significant at $1 \mathrm{~d}$ satisfied the following conditions: $\mathrm{t} 0 \mathrm{C}=\mathrm{t} 0 \mathrm{H}, 1 \mathrm{dH} \neq \mathrm{t} 0 \mathrm{C}, 1 \mathrm{dH} \neq \mathrm{t} 0 \mathrm{H}, 1 \mathrm{dH} \neq 1 \mathrm{dC}$. Genes that were significant at $2 \mathrm{~d}$ satisfied the following conditions: $\mathrm{t} 0 \mathrm{C}=\mathrm{t} 0 \mathrm{H}, 2 \mathrm{dH} \neq \mathrm{t} 0 \mathrm{C}, 2 \mathrm{dH} \neq \mathrm{t} 0 \mathrm{H}$, and $2 \mathrm{dH} \neq 2 \mathrm{dC}$. Genes that were significantly different at both days were the overlap between the 2 previous tests. Genes that were significantly different between $1 \mathrm{dH}$ and $2 \mathrm{dH}$ had to be among those genes that were significant on both days and also satisfied the additional test $1 \mathrm{dH} \neq$ $2 \mathrm{dH}$. Clustering of genes that were differentially expressed at both 1 and $2 \mathrm{~d}$ was performed in TIGR TMEV 4.0 (Saeed et al. 2003) using hierarchical clustering according to Euclidean distance and average linkage. To assess over-representation of gene ontology (GO) terms in the lists of significant genes, we used default values in GOEAST (Zheng \& Wang 2008) except that no correction was made for multiple testing, and the significance cutoff was set to $\alpha=0.01$. These parameters were empirically chosen as they produced results that were best reflected by the data. All clone annotations are available via our expressed sequence tag (EST) database: http://sequoia.ucmerced. edu/SymBioSys/index.php.

Quantitative real-time PCR (qRT-PCR). To validate and complement microarray gene expression patterns, qRT-PCR was performed for 3 housekeeping genes (HKGs) and 3 differentially expressed genes. Additionally, we quantified the expression of 8 genes to evaluate pathways that are thought to be involved in the cellular mechanisms of cnidarian bleaching. cDNAs were syn- thesized from $1 \mu \mathrm{g}$ of aRNA using SuperScript III reverse transcriptase (Invitrogen). cDNA synthesis reactions were diluted 10 -fold to a final volume of $200 \mu$ l. qRT-PCR primers (Table S1 available as supplementary material at www.int-res.com/articles/suppl/m402p097_app.xls) were designed using Primer Express 3.0 (Applied Biosystems) based on available Acropora palmata EST sequences, and test-PCRs confirmed the specific amplification of the desired amplicons (70 to $100 \mathrm{bp}$ ). Two $\mu \mathrm{l}$ of cDNA were used in triplicate $12.5 \mu \mathrm{l}$ qPCR reactions with $0.2 \mu \mathrm{M}$ primers and Power SYBR Green PCR Master Mix (Applied Biosystems) for 40 cycles. Six candidate HKGs were identified using previously described quantitative methods (Rodriguez-Lanetty et al. 2007). The 3 most stable HKGs were identified using geNORM software (Vandesompele et al. 2002). The pairwise variation in the normalization factor based on the 3 HKGs was 0.082 (less than the 0.15 cutoff suggested in Vandesompele et al. (2002)). The 3 HKGs were (1) AOKF904, BUD13 homolog $\left(E=1 \mathrm{e}^{-46}\right)$ : an mRNA splicing protein; (2) AOKF1782, Ribokinase $\left(E=8 \mathrm{e}^{-88}\right)$ : a protein involved in D-ribose metabolism; and (3) AOKF1657: a $\mathrm{Ca}^{2+}$ dependent protein kinase $\left(\mathrm{E}=6 \mathrm{e}^{-6}\right)$. Using calculations outlined in Vandesompele et al. (2002), the qRT-PCR expression values for the assayed genes were normalized to the geometric mean of the 3 HKGs. Statistical significance of qRT-PCR data was assessed on the normalized expression levels for each time point and treatment using SigmaStat 3.11. If normality and equal variance tests were satisfied, 1-way ANOVA and Holm-Sidak post-hoc testing were performed. If the normality test failed, Kruskal-Wallis 1-way ANOVA on ranks was performed with post-hoc testing via Dunn's method.

\section{RESULTS}

\section{Visual observations of bleaching and Symbiodinium cell densities}

Heat-treated Acropora palmata displayed a high, yet variable sensitivity to a $3^{\circ} \mathrm{C}$ temperature increase. While 1 replicate (colony 1 ) showed no appreciable bleaching after $1 \mathrm{~d}$ of stress, 2 replicates (colonies 2 and 4) showed definite slight bleaching, and the final replicate (colony 3) showed extreme bleaching. After $2 \mathrm{~d}$ of thermal stress, colonies 1 and 2 showed significant partial bleaching, and colony 4 displayed near-full bleaching.

Densities of Symbiodinium within the experimental coral fragments largely corroborate visual observations. After $1 \mathrm{~d}$ of thermal stress, colony 1 experienced no reduction in Symbiodinium density; colonies 2 and 4, roughly $50 \%$ reductions; and colony 3 , a $75 \%$ reduction. This high variability can be seen in Fig. 1 (high SD for the 


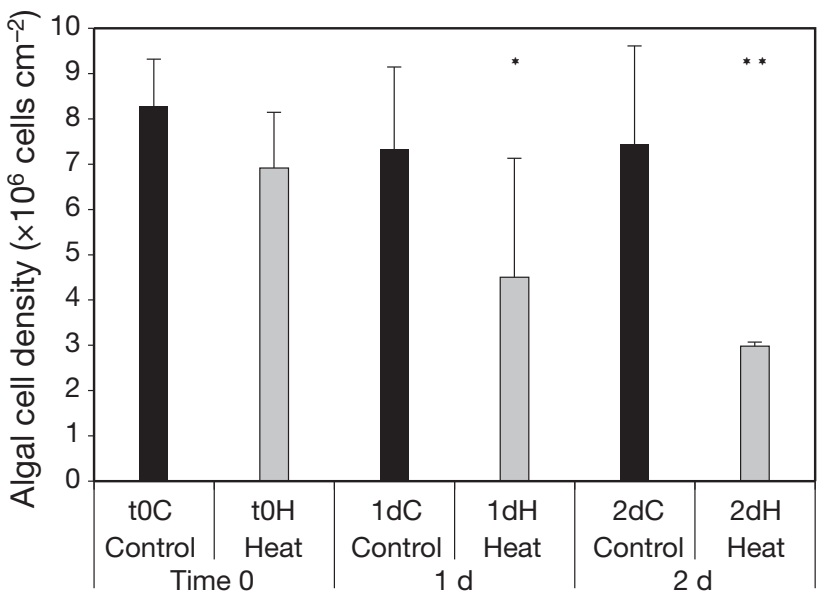

Fig. 1. Acropora palmata. Symbiodinium cell counts illustrating bleaching over $2 \mathrm{~d}$. Mean cell densities of 4 replicate fragments are shown with SDs. One-way ANOVA with posthoc pairwise testing via the Fisher LSD Method showed that the $1 \mathrm{~d}$ heated samples $\left({ }^{*}\right)$ were significantly different from the time 0 control samples only $(\mathrm{p}<0.01)$. The $2 \mathrm{~d}$ heated samples $\left({ }^{* *}\right)$ were significantly different from all nonheated samples $(\mathrm{p}<0.05)$

$1 \mathrm{~d}$ heated replicates). In contrast, the Symbiodinium densities of the 3 heat-stressed replicates displayed low variability after $2 \mathrm{~d}$. Colony 1 experienced a $60 \%$ reduction; colony 2 , a $50 \%$ reduction; and colony 4 , a $70 \%$ reduction. The 1-way ANOVA revealed a significant difference among the treatment groups ( $p=0.01)$, and post-hoc pairwise testing revealed significant differences in the following comparisons: t0C vs. $1 \mathrm{dH}(\mathrm{p}=$ 0.008); and all controls vs. $2 \mathrm{dH}$ ( $\mathrm{p}<0.05$ ) (Fig. 1).

Symbiodinium 18S rRNA gene RFLP genotyping analyses revealed that all fragments housed Symbiodinium clade A (data not shown). This finding is consistent with previous reports documenting the monoassociation of Acropora palmata with clade A (Baker et al. 1997).

\section{Microarray gene expression analysis}

Genes that were differentially expressed across the entire experiment represent the overlap between significant genes at 1 and $2 \mathrm{~d}$. Seventy-four genes showed stable expression among the non-heat-treated groups and marked changes upon thermal stress (Fig. 2). Of these 74 genes, 43 were down-regulated (56\% annotated), and 31 were up-regulated (58\% annotated). Fold changes and functional groupings for selected genes presented in Fig. 2 are listed in Table 1 (annotations and fold changes for all differentially expressed genes can be found in Table S2 available as supplementary material at www.int-res.com/articles/suppl/ m402p097_app.xls).
GOEAST identified 23 statistically over-represented GO terms among the list of 74 significant genes (Table S3 available as supplementary material at www. int-res.com/articles/suppl/m402p097_app.xls). Overrepresentation of the cellular component 'chromatin' (GO:0000785), the biological process 'DNA replication' (GO:0006260), and the molecular function 'chromatin binding' (GO:0003682) strongly suggests reduced DNA replication and cell division in heat-stressed samples since all of the differentially expressed genes in these categories were down-regulated (see 'Cell cycle regulation' in Table 1 and ' $C C^{\prime}$ superscript in Fig. 2). Additionally, the up-regulation of 11-cis retinol dehydrogenase (AOKF1403) and syntenin-1 (CAOH975), and the down-regulation of eyes absent homolog 3 (AOKG2092) led to the over-representation of the biological processes 'sensory perception' (GO:0007600) and 'neurological system process' (GO:0050877) (see 'Sensory perception' in Table 1).

We identified 204 differentially expressed genes in the $1 \mathrm{~d}$ heat-stressed samples. Of these 204 genes, 115 were up-regulated, and 89 were down-regulated following thermal stress. Approximately $54 \%$ of the upregulated genes were annotated, while $56 \%$ of the down-regulated genes were annotated. These 204 genes contain the 74 genes that were differentially expressed across the entire experiment, which leaves 130 genes that were unique to the $1 \mathrm{~d}$ samples. Some clear trends emerge from studying the 130 genes that were expressed after $1 \mathrm{~d}$ of thermal stress. Modification of the actin cytoskeleton, down-regulation of cell cycle transcripts, up-regulation of protein-folding transcripts, up-regulation of transport transcripts, and differential expression of many signaling molecules and transcription factors emerge as the cellular processes that were effected following $1 \mathrm{~d}$ of thermal stress (Table 1). GOEAST over-representation analysis of these 130 genes corroborates some of these findings. For example, the molecular functions 'heat shock protein binding' (GO:0031072) and 'transcription factor activity' (GO:0003700) were over-represented. In addition, the up-regulation of polyadenylate-binding protein 4 (AOKF1142), selenoprotein $\mathrm{S}$ (AOKF908), and transcriptional repressor NF-X1 (AOKG1293) transcripts led to the over-representation of the biological processes 'response to external stimulus' (GO:0009605) and 'inflammatory response' (GO:0006954) (Table S3).

In the $2 \mathrm{~d}$ heat-stressed samples, 105 genes were differentially expressed. Of these 105 genes, 44 were upregulated, and 61 were down-regulated following thermal stress. Approximately $56 \%$ of the up-regulated genes were annotated, while $61 \%$ of the down-regulated genes were annotated. Again, these 105 genes contain the 74 genes that were significant across the entire experiment, which leaves 31 genes that were 


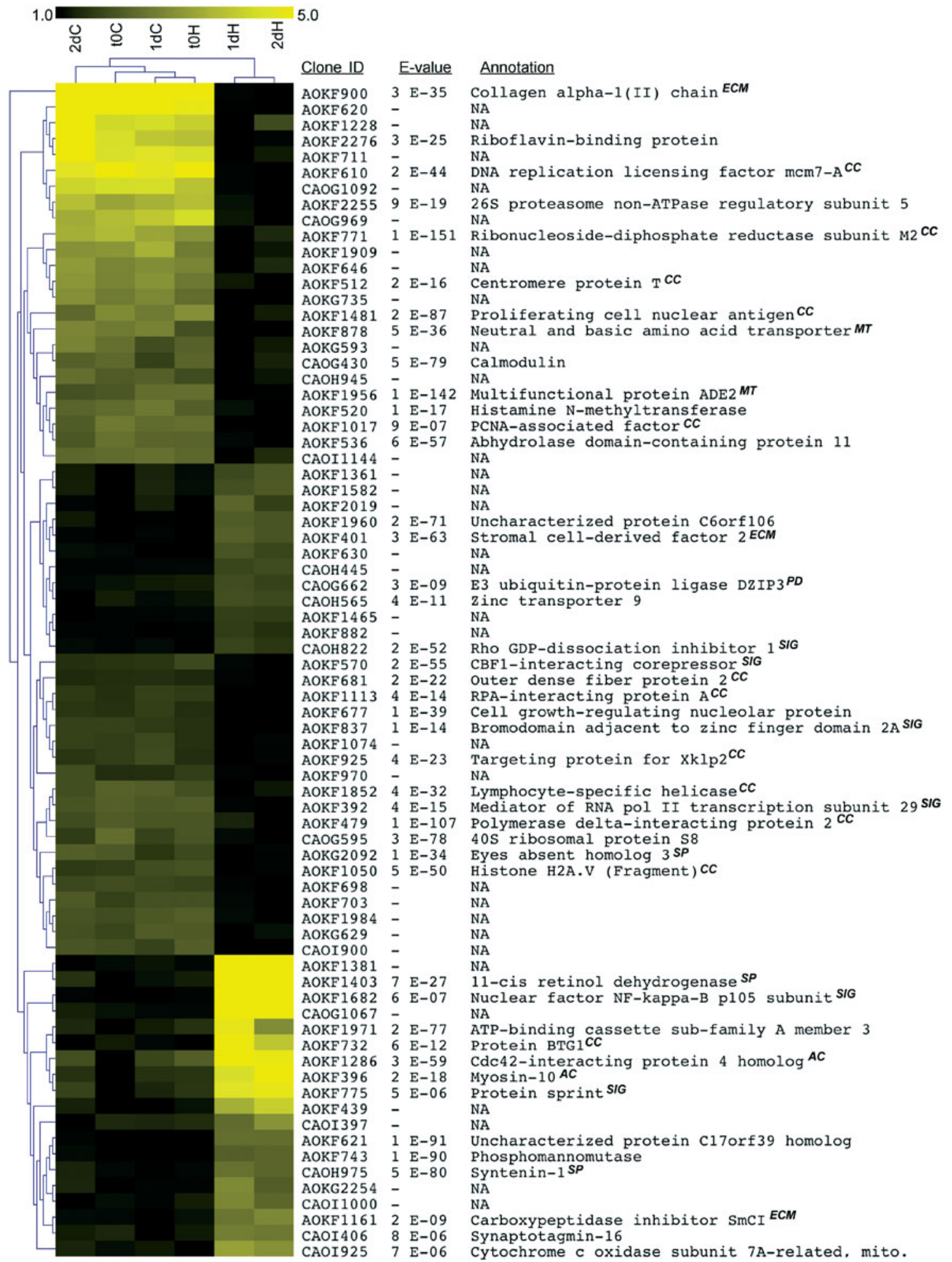

Fig. 2. Acropora palmata. Heat map of genes that are differentially expressed at both 1 and $2 \mathrm{~d}$ post-heat stress. For each gene, BAGEL assigns the value of 1 to the class with the lowest expression, and calculates the expression of the other classes relative to 1 . Thus, down-regulated genes have values that are $>1$ in the controls and approach 1 in the heat-stressed samples. Conversely, in up-regulated genes, the control values approach 1 and the heat stressed samples have values that are $>1$. Superscripts in the functional annotation column denote categories used in Table 1: $C C=$ cell cycle regulation; $S I G=$ cell signaling/transcription factor activity; $E C M=$ extracellular matrix proteins; $S P=$ sensory perception; $P D=$ protein degradation; $A C=$ actin cytoskeleton; and $M T=$ metabolite transfer. In the scale bar: $\mathrm{t} 0,1 \mathrm{~d}, 2 \mathrm{~d}=$ time; $\mathrm{C}=$ control sample; $\mathrm{H}=$ heated sample. 
Table 1. Acropora palmata. Significantly differentially expressed genes identified in a cDNA microarray experiment comparing gene expression between control and heat-stressed fragments from 4 colonies. Common names and E-values are for the top BLAST hit to the SwissProt database. Fold changes in $1 \mathrm{~d}$ and $2 \mathrm{~d}$ heat-stressed fragments $(1 \mathrm{dH}$ and $2 \mathrm{dH})$ are relative to the average of the 4 control groups ( $\mathrm{t} 0 \mathrm{C}, \mathrm{t} 0 \mathrm{H}, 1 \mathrm{dC}$, and $2 \mathrm{dC}$ ). -: not significant

\begin{tabular}{|c|c|c|c|c|}
\hline \multirow[t]{2}{*}{ Clone ID } & \multirow{2}{*}{ Common name } & \multirow{2}{*}{ E-value } & \multicolumn{2}{|c|}{ Fold change } \\
\hline & & & $1 \mathrm{dH}$ & $2 \mathrm{dH}$ \\
\hline \multicolumn{5}{|c|}{ Cell cycle regulation } \\
\hline AOKG1979 & Cell division cycle protein 20 homolog & $1 E-129$ & -1.53 & - \\
\hline AOKF610 & DNA replication licensing factor $\mathrm{mcm} 7-\mathrm{A}$ & $2 \mathrm{E}-44$ & -4.66 & -5.03 \\
\hline CAOH556 & G1/S-specific cyclin-D2 & $7 \mathrm{E}-80$ & -2.53 & - \\
\hline AOKF732 & Protein BTG1 & $6 \mathrm{E}-12$ & 4.49 & 3.56 \\
\hline AOKF1223 & Protein regulator of cytokinesis 1 & $1 \mathrm{E}-35$ & -1.84 & - \\
\hline AOKF1767 & Ribonucleoside-diphosphate reductase large subunit & $1 \mathrm{E}-107$ & -2.20 & - \\
\hline AOKF771 & Ribonucleoside-diphosphate reductase subunit M2 & $1 \mathrm{E}-151$ & -3.40 & -2.44 \\
\hline \multicolumn{5}{|c|}{ Cell signaling / transcription factor activity } \\
\hline CAOH623 & cAMP-responsive element-binding protein-like 2 & $2 \mathrm{E}-18$ & 2.32 & - \\
\hline AOKF917 & Cyclic AMP-dependent transcription factor ATF-2 & $8 \mathrm{E}-31$ & 2.70 & - \\
\hline CAOH936 & Cyclic AMP-dependent transcription factor ATF-4 & $1 \mathrm{E}-13$ & 2.42 & - \\
\hline $\mathrm{CAOH} 485$ & NF-кB p105 subunit (Ankyrin repeat domain) & $2 \mathrm{E}-37$ & 2.01 & - \\
\hline AOKF1682 & NF-кB p105 subunit (Death domain) & $6 \mathrm{E}-07$ & 7.12 & 5.57 \\
\hline AOKF1550 & Nuclear factor erythroid 2-related factor 3 & $5 \mathrm{E}-08$ & 2.99 & - \\
\hline AOKF942 & Nuclear factor erythroid 2-related factor 3 & $5 \mathrm{E}-08$ & 2.77 & - \\
\hline AOKF775 & Protein sprint & $5 \mathrm{E}-06$ & 3.28 & 3.42 \\
\hline AOKF1938 & Receptor-type tyrosine-protein phosphatase alpha & $6 \mathrm{E}-45$ & 1.83 & - \\
\hline AOKF494 & Serine/threonine-protein kinase 6 & $1 \mathrm{E}-109$ & - & -1.96 \\
\hline AOKF654 & Transcription initiation factor TFIID subunit 13 & $5 \mathrm{E}-21$ & - & -1.71 \\
\hline AOKG1293 & Transcriptional repressor NF-X1 & $8 \mathrm{E}-36$ & 1.59 & - \\
\hline CAOI879 & Transmembrane emp24 domain-containing protein 1 & $2 \mathrm{E}-25$ & - & 1.58 \\
\hline \multicolumn{5}{|c|}{ Extracellular matrix proteins } \\
\hline AOKF1161 & Carboxypeptidase inhibitor SmCI & $2 \mathrm{E}-09$ & 2.26 & 2.56 \\
\hline AOKF900 & Collagen alpha-1(II) chain & $3 \mathrm{E}-35$ & -20.69 & -22.16 \\
\hline AOKF939 & Papilin & $2 \mathrm{E}-12$ & - & 1.89 \\
\hline AOKF401 & Stromal cell-derived factor 2 & $3 \mathrm{E}-63$ & 2.08 & 1.90 \\
\hline AOKF1669 & Tolloid-like protein 2 & $2 \mathrm{E}-30$ & 1.49 & - \\
\hline \multicolumn{5}{|c|}{ Sensory perception } \\
\hline AOKF1403 & 11-cis retinol dehydrogenase & $7 \mathrm{E}-27$ & 7.99 & 6.39 \\
\hline AOKF2211 & Cryptochrome-1 & $9 \mathrm{E}-74$ & 1.54 & - \\
\hline AOKG2092 & Eyes absent homolog 3 & $1 \mathrm{E}-34$ & -1.91 & -1.73 \\
\hline CAOH975 & Syntenin-1 & $5 \mathrm{E}-80$ & 2.14 & 1.96 \\
\hline \multicolumn{5}{|c|}{ Protein degradation } \\
\hline CAOG662 & E3 ubiquitin-protein ligase DZIP3 & $3 \mathrm{E}-09$ & 1.54 & 1.41 \\
\hline AOKF1969 & E3 ubiquitin-protein ligase NRDP1 & $6 \mathrm{E}-52$ & 2.40 & - \\
\hline AOKF1154 & Ubiquitin & $4 \mathrm{E}-35$ & 1.49 & - \\
\hline AOKG649 & Ubiquitin-conjugating enzyme E2 A & $1 \mathrm{E}-78$ & 2.85 & - \\
\hline \multicolumn{5}{|c|}{ Actin cytoskeleton } \\
\hline CAOH739 & Actin, cytoplasmic & $0 \mathrm{E}+00$ & -2.28 & - \\
\hline CAOG410 & Gelsolin & $1 \mathrm{E}-47$ & -1.82 & - \\
\hline AOKF396 & Myosin-10 & $2 \mathrm{E}-18$ & 3.18 & 3.63 \\
\hline CAOH671 & Myosin-2 essential light chain & $4 \mathrm{E}-25$ & -1.80 & - \\
\hline AOKF554 & Tropomyosin & $8 \mathrm{E}-14$ & - & -2.13 \\
\hline AOKF1962 & Tropomyosin-2 & $2 \mathrm{E}-21$ & -1.53 & - \\
\hline \multicolumn{5}{|c|}{ Heat shock proteins } \\
\hline CAOH1088 & DnaJ homolog subfamily A member 2 & $1 \mathrm{E}-10$ & 1.83 & - \\
\hline AOKF1222 & DnaJ homolog subfamily B member 11 & $1 \mathrm{E}-112$ & 2.11 & - \\
\hline AOKG405 & Heat shock cognate $71 \mathrm{kDa}$ protein & $2 \mathrm{E}-38$ & 1.56 & - \\
\hline AOKF986 & Heat shock protein HSP 90-alpha & $0 \mathrm{E}+00$ & 2.20 & - \\
\hline \multicolumn{5}{|c|}{ Metabolite transfer } \\
\hline AOKF1308 & 1,4- $\alpha$-glucan-branching enzyme & $6 \mathrm{E}-30$ & - & -2.08 \\
\hline CAOG693 & Carnitine O-acetyltransferase & $5 \mathrm{E}-61$ & - & 1.86 \\
\hline AOKG2283 & Glyceraldehyde-3-phosphate dehydrogenase & $5 E-163$ & -2.17 & - \\
\hline AOKF1837 & Isocitrate lyase & $1 \mathrm{E}-151$ & - & 2.85 \\
\hline
\end{tabular}


Table 1 (continued)

\begin{tabular}{|c|c|c|c|c|}
\hline \multirow{2}{*}{ Clone ID } & \multirow{2}{*}{ Common name } & \multirow{2}{*}{ E-value } & \multicolumn{2}{|c|}{ Fold change } \\
\hline & & & $1 \mathrm{dH}$ & $2 \mathrm{dH}$ \\
\hline \multicolumn{5}{|c|}{ Metabolite transfer } \\
\hline AOKF1692 & Methylenetetrahydrofolate reductase & $1 \mathrm{E}-22$ & -1.86 & - \\
\hline AOKF1956 & Multifunctional protein ADE2 & $1 \mathrm{E}-142$ & -2.21 & -2.14 \\
\hline AOKF878 & Neutral and basic amino acid transporter & $5 \mathrm{E}-36$ & -2.53 & -2.51 \\
\hline AOKF818 & Synaptic glycoprotein SC2 & $2 \mathrm{E}-88$ & - & -2.23 \\
\hline CAOH1099 & Vitellogenin-2 & $4 \mathrm{E}-22$ & -5.74 & - \\
\hline \multicolumn{5}{|c|}{ Ribosomal proteins } \\
\hline CAOH815 & 40S ribosomal protein $\mathrm{S} 15 \mathrm{a}$ & $6 \mathrm{E}-60$ & - & -1.76 \\
\hline CAOG595 & 40S ribosomal protein S8 & $3 \mathrm{E}-78$ & -1.70 & -1.95 \\
\hline $\mathrm{CAOH} 441$ & $60 \mathrm{~S}$ acidic ribosomal protein P1 & $2 \mathrm{E}-17$ & - & -1.82 \\
\hline CAOG952 & 60 S ribosomal protein L11 & $5 \mathrm{E}-82$ & - & -1.47 \\
\hline \multicolumn{5}{|c|}{$\mathrm{Ca} 2+$ homeostasis proteins } \\
\hline AOKF800 & Calcyphosin-like protein & $5 \mathrm{E}-52$ & - & -2.04 \\
\hline CAOG430 & Calmodulin & $5 \mathrm{E}-79$ & -2.12 & -1.60 \\
\hline CAOI402 & Sarcoplasmic reticulum histidine-rich Ca-binding protein & $7 \mathrm{E}-15$ & -1.85 & - \\
\hline AOKF1965 & Troponin C, skeletal muscle & $1 \mathrm{E}-11$ & -1.84 & \\
\hline \multicolumn{5}{|c|}{ Oxidative stress } \\
\hline AOKG480 & Glutaredoxin-3 & $1 E-110$ & 1.94 & - \\
\hline AOKF1142 & Polyadenylate-binding protein 4 & $2 \mathrm{E}-55$ & 1.51 & - \\
\hline AOKF908 & Selenoprotein S & $2 \mathrm{E}-20$ & 1.80 & - \\
\hline \multicolumn{5}{|c|}{ Vesicle/ion/macromolecule transport } \\
\hline AOKF1016 & ADP-ribosylation factor GTPase-activating protein 3 & $2 \mathrm{E}-27$ & 1.74 & - \\
\hline AOKF1971 & ATP-binding cassette sub-family A member 3 & $2 \mathrm{E}-77$ & 3.74 & 2.26 \\
\hline AOKF1543 & BTB/POZ domain-containing protein KCTD7 & $3 \mathrm{E}-18$ & - & -1.58 \\
\hline CAOH817 & Pituitary tumor-transforming gene 1 interacting protein & $2 \mathrm{E}-20$ & 2.41 & - \\
\hline CAOH1006 & Protein RER1 & $4 \mathrm{E}-54$ & 2.15 & - \\
\hline AOKF821 & Vacuolar proton pump subunit E & $7 \mathrm{E}-66$ & 1.64 & - \\
\hline \multicolumn{5}{|l|}{ Miscellaneous } \\
\hline AOKF1649 & Apoptosis regulator R1 (Fragment) & $1 \mathrm{E}-20$ & 1.65 & - \\
\hline AOKG615 & Atrial natriuretic receptor A & $7 \mathrm{E}-47$ & 1.68 & - \\
\hline AOKF638 & Cytochrome b-245 light chain & $2 \mathrm{E}-36$ & 1.70 & - \\
\hline AOKG407 & Endothelin-converting enzyme 1 & $1 \mathrm{E}-16$ & 2.19 & - \\
\hline AOKF2276 & Riboflavin-binding protein & $3 \mathrm{E}-25$ & -4.68 & -4.30 \\
\hline
\end{tabular}

uniquely expressed at $2 \mathrm{~d}$ of heat stress. Some notable differentially expressed genes are listed in Table 1 . The up-regulation of isocitrate lyase (AOKF1837), 1,4- $\alpha$ glucan-branching enzyme (AOKF1308), synaptic glycoprotein SC2 (AOKF818), and carnitine O-acetyltransferase (CAOG693) transcripts led to the statistically significant over-representation of the GO biological processes 'carbohydrate metabolic process' (GO:00059 75), 'carboxylic acid metabolic process' (GO:0019752), and 'lipid metabolic process' (GO:0006629). Another notable over-represented GO category was the cellular component 'ribonucleoprotein complex' (GO:0030529), which was represented by the down-regulation of 3 ribosomal protein transcripts and the up-regulation of La-related protein 7 transcripts (Table S3).

We were also interested in genes that were differentially expressed between $1 \mathrm{dH}$ and $2 \mathrm{dH}$. Among the 74 genes that were significant across the entire experiment (Fig. 2), only 2 genes were significantly different between $1 \mathrm{dH}$ and $2 \mathrm{dH}$. NF-кB p105 subunit (Death do- main, AOKF1682) decreased in expression from $1 \mathrm{dH}$ to $2 \mathrm{dH}$, as did CAOI1144 (non-annotated). Thus, over $90 \%$ of the genes that were differentially expressed at both 1 and $2 \mathrm{~d}$ did not change expression as bleaching progressed.

\section{Quantitative real-time PCR}

For the 3 genes that we validated via qRT-PCR, the direction of change was consistent with the microarray results. However, their normalized expression estimates were less than (26S proteasome non-ATPase regulatory subunit 5), greater than (11-cis retinol dehydrogenase), or highly similar to $(\mathrm{NF}-\kappa \mathrm{B})$ the microarray-estimated fold changes (Table 2). Instead of confirming the significance of more differentially expressed genes, we chose to assay 8 genes that were not present on the microarray in order to evaluate pathways that are thought to be involved in the cellular mechanisms of cnidarian bleach- 
Table 2. Acropora palmata. Results of qRT-PCR analyses on control and heat-stressed fragments from 4 colonies. We validated the microarray-based results for the first 3 genes listed, and chose an additional 8 genes that were not present on the microarray to further implicate certain cellular processes involved in the thermal stress response and bleaching. Common names and E-values are for the top BLAST hit to the SwissProt database. Similar to the microarray data output from BAGEL, we set the lowest expression class to 1 and calculated the expression of the other classes relative to 1. qRT-PCR-estimated expression for the controls is represented by the mean of the 4 control groups ( $\mathrm{t} 0 \mathrm{C}, \mathrm{t} 0 \mathrm{H}, 1 \mathrm{dC}$, and $2 \mathrm{dC}$ ). ( $\left.{ }^{*}\right)$ Statistically significant differences ( $<0.05$ ) in the heat-stressed samples ( $1 \mathrm{dH}$ and $2 \mathrm{dH})$ (1-way ANOVA and post-hoc testing)

\begin{tabular}{|c|c|c|c|c|c|c|c|}
\hline \multirow[t]{2}{*}{ Clone ID } & \multirow[t]{2}{*}{ Common name } & \multirow[t]{2}{*}{ E-value } & \multirow{2}{*}{$\begin{array}{c}\text { qRT-PCR } \\
\text { controls } \\
(\text { Mean } \pm \text { SD) }\end{array}$} & \multicolumn{2}{|c|}{ Heat-stressed } & \multicolumn{2}{|c|}{$\begin{array}{l}\text { Microarray } \\
\text { fold change }\end{array}$} \\
\hline & & & & & & $1 \mathrm{dH}$ & $2 \mathrm{dH}$ \\
\hline AOKF1403 & 11-cis retinol dehydrogenase & $7 \mathrm{E}-27$ & $2.10 \pm 1.67$ & $56.38^{*}$ & $186.76^{*}$ & 7.99 & 6.39 \\
\hline AOKF1682 & NF-кB p105 (Death domain) & $6 \mathrm{E}-07$ & $1.21 \pm 0.26$ & $7.91^{*}$ & $5.45^{*}$ & 7.12 & 5.57 \\
\hline AOKF2255 & 26S proteasome non-ATPase reg. subunit 5 & 9E-19 & $1.77 \pm 0.08$ & $1.06^{*}$ & $1.0^{*}$ & -3.08 & -3.62 \\
\hline CCHX1276 & CuZn superoxide dismutase $(\mathrm{Cu} / \mathrm{ZnSOD})$ & $2 \mathrm{E}-56$ & $1.17 \pm 0.12$ & 1.50 & 1.0 & - & - \\
\hline CCHX14559.b1 & NOS-interacting protein (NOSIP) & $3 E-60$ & $1.56 \pm 0.15$ & $1.12^{*}$ & $1.0^{*}$ & - & - \\
\hline CCHX13018.g1 & E3 ubiquitin-protein ligase Mdm2 & $3 E-13$ & $1.30 \pm 0.25$ & 1.01 & 1.09 & - & - \\
\hline CCHX1211 & TP53-regulated inhibitor of apoptosis 1 & $5 \mathrm{E}-16$ & $2.35 \pm 0.33$ & $1.21^{*}$ & $1.0^{*}$ & - & - \\
\hline CCHX2749.b1 & Autophagy-related protein 12 & $6 \mathrm{E}-24$ & $2.19 \pm 0.43$ & $1.16^{*}$ & $1.0^{*}$ & - & - \\
\hline CCHX15353.b1 & Caspase-3 & $4 \mathrm{E}-36$ & $1.06 \pm 0.06$ & 1.06 & 1.03 & - & - \\
\hline CCHX4259.b1 & TNF receptor-assoc. factor 3 (TRAF3) & $6 \mathrm{E}-53$ & $1.27 \pm 0.22$ & $27.04^{*}$ & $29.24^{*}$ & - & - \\
\hline СCHX9815 & NF-кB p105 (Rel homology domain) & $1 \mathrm{E}-38$ & $1.96 \pm 0.77$ & $12.97^{*}$ & $13.29^{*}$ & - & - \\
\hline
\end{tabular}

ing. Three of these 8 genes were not significantly differentially expressed in the thermally stressed samples $(\mathrm{Cu} / \mathrm{ZnSOD}, \mathrm{E} 3$ ubiquitin-protein ligase Mdm2, and caspase-3). Of the remaining 5 genes, 2 were up-regulated upon thermal stress: TNF receptor-associated factor 3 (TRAF3) and NF-кB p105 (Rel homology domain); and 3 were down-regulated upon thermal stress: nitric oxide synthase-interacting protein (NOSIP), TP53-regulated inhibitor of apoptosis 1 (p53CV), and autophagy-related protein 12 .

\section{DISCUSSION}

\section{Cellular stress response of Acropora palmata}

Many differentially expressed genes identified in the present study are involved in the cellular stress response, which can be defined as the response of the coral to stress-induced damage to cellular macromolecules. In the case of symbiotic corals, multiple stressors can lead to bleaching. For example, thermal stress causes bleaching, but the bleaching process is invariably the result of both thermal and oxidative stress (Lesser 1997) since thermal stress causes reactive oxygen species (ROS) formation in the host mitochondria (Dykens et al. 1992, Nii \& Muscatine 1997), and heat and light stress causes ROS generation in Symbiodinium chloroplasts (Jones et al. 1998, Lesser 2006). As the number of endosymbionts dwindles and metabolites cease to be transferred from endosymbiont to host and vice versa, osmotic stress is produced (Mayfield \& Gates 2007).
Our results provide solid evidence of thermal and oxidative stress, and include possible signatures of osmotic stress. We identified transcripts encoding 4 heat shock proteins (HSPs) that were up-regulated in the $1 \mathrm{~d}$ samples (Table 1). Interestingly, no HSPs were differentially expressed in the $2 \mathrm{~d}$ samples, which is consistent with the idea that HSP expression ramps up in waves that are consistent with protein turnover (Gates \& Edmunds 1999). With respect to oxidative stress, the up-regulation of transcripts encoding glutaredoxin-3 (AOKG480) and selenoprotein S (AOKF908) represents increased protective mechanisms against ROS. Additionally, oxidative stress-responsive transcription factors were up-regulated during thermal stress: nuclear factor erythroid 2-related factor 3 (Nrf3) homologs (AOKF942 and AOKF1550) (Vargas et al. 2006) and cAMP-dependent transcription factor ATF4 (CAOH936) (Harding et al. 2003). Interestingly, copper/zinc superoxide dismutase (Cu/ZnSOD, CCHX1276), which was measured via qRT-PCR, was not significantly up-regulated in thermally stressed samples, although the $1 \mathrm{~d}$ stressed samples had an increase in expression (Table 2). This protein was previously shown to increase in expression during thermal and light stress (Downs et al. 2000, Lesser \& Farrell 2004). The low light levels during our experiments may explain the insignificant $\mathrm{Cu} / \mathrm{ZnSOD}$ up-regulation. With respect to osmotic stress, the up-regulation of transcripts involved in ion/macromolecular transport (Table 1) may indicate osmoregulation. In our earlier study on Montastraea faveolata (DeSalvo et al. 2008), we observed transcriptomic signatures of heat and oxidative stress but not of osmotic stress. 


\section{Growth arrest}

As discussed by Kultz (2003), the cellular stress response is highly conserved in all organisms, and includes 4 main mechanisms: (1) growth arrest; (2) upregulation of chaperones (see previous paragraph); (3) nucleic acid stabilization and repair; and (4) removal of damaged macromolecules. We found a marked downregulation of numerous genes involved in DNA replication and cell cycle progression in the present study (Table 1, Fig. 2). Suppressing cell proliferation during stress conserves energy and ensures that cells with damaged DNA do not divide. This transcriptomic response was found in fish (Gillichthys mirabilis) that was exposed to hypoxia (Gracey et al. 2001) and thermal stress (Buckley et al. 2006), and in murine kidney cells in response to hyperosmotic stress (Kultz et al. 1998). The need to conserve energy during cellular stress is also the likely reason behind the observed down-regulation of ribosomal protein transcripts, which is consistent with previous studies in yeast (Herruer et al. 1988), Drosophila (Bell et al. 1988), and Montastraea faveolata (DeSalvo et al. 2008).

\section{Nucleic acid stabilization and repair}

Our results do not show the up-regulation of classic DNA repair proteins; however, Kultz (2003) mentioned p53 and NF- $\mathrm{B}$ as eukaryotic pathways involved in DNA repair and chromatin stabilization. The p53 transcription factor was previously found to be up-regulated during heat and light stress in Montastraea faveolata (Lesser \& Farrell 2004). p53 is not present on our microarray, nor is it present in our Acropora palmata EST libraries. However, we quantified the expression of 2 genes within the p53 pathway using qRT-PCR: E3 ubiquitin-protein ligase Mdm2 (CCHX13018.g1) and TP53-regulated inhibitor of apoptosis 1, also known as p53CSV (CCHX1211) (Table 2). Mdm2-p53 binding prevents p53 from acting as a transcription factor and targets p53 for proteolytic degradation (Prives \& Hall 1999). Mdm2 was not differentially expressed in A. palmata. While Mdm2 down-regulation would have suggested p53 activation, our results suggest that corals may regulate p53 activity via phosphorylation and acetylation, which is consistent with other study systems (Prives \& Hall 1999). p53CSV mediates survival in a p53dependent manner (Park \& Nakamura 2005). We found this gene to be 2-fold down-regulated in thermally stressed samples. Interestingly, Park \& Nakamura (2005) found that p53CSV was not induced during severe DNA damage. Thus, our results indicate either severe DNA damage, or lack of p53 activation.
The NF- $\mathrm{BB}$ family of transcription factors regulates genes that control cell death, cell adhesion, innate immunity, proliferation, inflammation, the cellular stress response, and tissue remodeling (Perkins 2007). One member of this family is the NF- $\mathrm{BB}$ p105 precursor, which encodes a protein that contains a Rel homology domain (RHD), an ankyrin repeat domain (ARD), and a death domain (DD). The p105 precursor is posttranslationally modified to generate the p50 subunit (RHD-containing transcription factor) and I- $\kappa \mathrm{B}$ (an inhibitor of the p50 subunit containing the ARD and DD) (Pereira \& Oakley 2008). Differences in NF- $\kappa B$ p105 gene architecture are apparent in cnidarians. In Nematostella vectensis, all characterized NF-кB genes lack the I- $\kappa B$-like sequences; however, loci that are

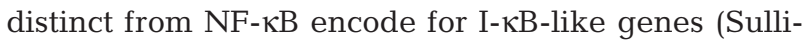
van et al. 2007). Our results show the up-regulation of transcripts encoding 2 proteins that contain homology to NF-кB p105: (1) CAOH485 (2-fold up-regulated at $1 \mathrm{~d}$ ), which contains the ARD; and (2) AOKF1682 (over 5 -fold up-regulated on both days), which contains the DD (Table 1). Additionally, we performed qRT-PCR on CCHX9815, another EST with homology to NF-кB p105 (containing the RHD) and found it to be over 5-fold up-regulated in the heat-stressed samples (Table 2). Based on our most current EST assembly, CAOH485 (an I-kB-like sequence) and CCHX99815 (an NF- $\kappa \mathrm{B}$-like sequence) contain a poly-A tail, but AOKF1682 does not. While further sequencing is needed to resolve NF- $\mathrm{B}$ p105 gene architecture in Acropora palmata, our results preliminarily indicate that the gene architecture in A. palmata is similar to that in $N$. vectensis in that NF- $\mathrm{B}$ genes may be encoded by loci that are distinct from I- $\kappa \mathrm{B}$ genes. We also quantified the expression of TNF receptor-associated factor 3 (TRAF3-CCHX4259.b1), which is a protein involved in the activation of NF- $\kappa$, via $q R T-P C R$. TRAF3 was up-regulated over 20-fold in heat-stressed samples (Table 2). Interestingly, the expression levels of the I-кB-like sequences became nonsignificant (CAOH485) or decreased (AOKF1682) after $2 \mathrm{~d}$ of stress, but the levels of the transcription factor and the activator increased. These results show for the first time the role of NF- $\mathrm{KB}$ in signaling mechanisms during coral bleaching and suggest that the balance between $\mathrm{NF}-\kappa \mathrm{B}$ inhibition and activation may have been tipped towards activation in our experiment.

\section{Removal of damaged macromolecules}

Thermal and oxidative damage to cellular proteins leads to increased protein degradation via ubiquitin/ proteasome-mediated proteolysis. In the context of coral health, increased protein levels of ubiquitin were 
found in stressed corals (Downs et al. 2000, 2002, 2005). We clearly see up-regulation of transcripts involved in protein degradation. Ubiquitin (AOKF1154), E3 ubiquitin protein ligase NRDP1 (AOKF1969), and ubiquitin-conjugating enzyme E2A (AOKG649) were 1.5- to 2.9-fold up-regulated at $1 \mathrm{~d}$. Furthermore, E3 ubiquitin protein ligase DZIP3 (CAOG662) was upregulated at both days (Table 1 ). The up-regulation of ubiquitin and ubiquitin-conjugating enzyme E2A clearly suggests increased targeting of proteins for degradation in the proteasome.

When stress intensity increases to a point at which the organism can no longer maintain homeostasis, cell death pathways are often initiated as part of the stress response (Kultz 2003). Apoptosis, or programmed cell death, has received considerable attention in the coral bleaching field, and indeed, numerous studies have found apoptotic bodies or apoptosis molecular markers in bleached tissue preparations (reviewed by Weis 2008). Two additional bleaching mechanisms have recently been studied in symbiotic cnidarians: autophagy, the process by which a cell degrades its own components, e.g. organelles (Dunn et al. 2007); and symbiophagy, an autophagic process whereby the host consumes its endosymbiont (Downs et al. 2009).

Our previous study (DeSalvo et al. 2008) contained 2 pro-apoptotic signals; however, the present study contains both pro- and anti-apoptotic signals. Transcriptional repressor NF-X1 (AOKG1293) and polyadenylatebinding protein 4 (PABP4, AOKF1142), whose transcripts were both up-regulated at $1 \mathrm{~d}$ (Table 1), together stimulate telomerase reverse transcriptase, which enhances anti-apoptotic signaling during oxidative stress (Katzenellenbogen et al. 2007). The up-regulation of apoptosis regulator R1 (AOKF1649) is also antiapoptotic. This gene is a member of the Bcl-2 family, which contains potent inhibitors of cell death (Hockenbery et al. 1990, Shimizu et al. 1996, Clem et al. 1998). We measured the mRNA transcript levels of caspase-3 (CCHX15353.b1) via qRT-PCR and found that the gene was not differentially expressed during thermal stress (Table 2). This likely reflects previous findings that caspase-3, which is an executioner caspase, requires activation via post-translational modification (Boatright \& Salvesen 2003). The only pro-apoptotic signal among the differentially expressed genes was the aforementioned down-regulation of TP53-regulated inhibitor of apoptosis 1 (CCHX1211). This protein mediates survival by inhibiting the activation of caspases (Park \& Nakamura 2005), thus down-regulation would seem to be proapoptotic. Simultaneous pro- and anti-apoptotic signals likely point to tissue-specific responses to thermal stress.

Autophagy and symbiophagy also represent mechanisms by which the coral can rid itself of damaged macromolecules, organelles, and endosymbionts. We quantified the transcript abundance of autophagyrelated protein 12 (CCHX2749.b1) via qRT-PCR and found it to be nearly 2-fold down-regulated in stressed Acropora palmata (Table 2). Since this protein is required for autophagy (Mizushima et al. 1998), this result provides evidence against autophagic processes occurring in the present experiment.

\section{Other patterns of differential gene expression}

Restructuring of the extracellular matrix (ECM)

Thermal stress and bleaching in Acropora palmata was marked by a strong differential expression of ECM protein transcripts (Table 1). Collagen $\alpha-1$ (II) chain (AOKF900) was the most differentially expressed gene in the experiment-over 20-fold down-regulated in both 1 and $2 \mathrm{~d}$ samples. Interestingly, the ortholog of AOKF900 in Montastraea faveolata (AOSF1268) was also down-regulated during bleaching (DeSalvo et al. 2008). The down-regulation of collagen indicates either (1) reduced calcification during stress since this type of collagen is an ECM structural constituent (GO:0005201) that is involved in chondrocyte differentiation and skeleton formation in vertebrates (Cheah et al. 1991, Li et al. 1995); or (2) modified cell adhesion properties since ECM deposition in coral cells (composed mainly of collagen) was previously shown to mediate cell-cell and cell-substrate adhesion (Helman et al. 2008). Disrupted cell adhesion in A. palmata may point to bleaching via cell detachment (Gates et al. 1992). The remaining differentially expressed ECM genes were up-regulated in the stressed samples. Papilin (AOKF939) and carboxypeptidase inhibitor SmC1 (AOKF1161) are both Kunitz-type serine protease inhibitors. The activities of these enzymes warrant further study since the ortholog of AOKF1161 in M. faveolata (AOSF907) was responsive to thermal stress (DeSalvo et al. 2008), and a protein with a Kunitz domain was also identified in Anthopleura elegantissima that was exposed to UV stress (Richier et al. 2008). Tolloid-like protein 2 (AOKF1669), an ECM matrix metalloprotease that is involved in skeletogenesis (Scott et al. 1999), is also a candidate for further study.

\section{Sensory perception}

Another group of differentially expressed genes in Acropora palmata are related to 'neurological system processes' (GO:0050877) and 'visual perception' (GO: 0007601). 11-cis retinol dehydrogenase (AOKF1403, 8and 6.4-fold up-regulated at 1 and $2 \mathrm{~d}$, respectively) catalyzes the final step in the biosynthesis of 11-cis 
retinaldehyde, which is the universal chromophore of visual pigments. Cnidarian visual ecology consists of a large body of literature dedicated to the camera-type eye of the cubozoan Tripedalia cystophora (e.g. Kozmik et al. 2008) and eyeless photoreception in Hydra (e.g. Santillo et al. 2006). It is worthy to note that our A. palmata EST libraries include other vision-related genes such as micropthalmia-associated transcription factor Mitf (CCHX11178), opsin-1 (CCHX12957.b1), and phosducin-like protein (CCHX14045.b1). Additionally, cryptochrome-1 (AOKF2211, involved in circadian rhythms) was up-regulated 1.5-fold at $1 \mathrm{~d}$. How these sensory perception proteins may be involved in thermal stress responses, bleaching, or be affected by the breakdown of symbiosis is unknown. Since the control aquaria received roughly $10 \%$ more light than the heated aquaria, there is also the possibility that the differential expression of sensory genes was confounded by the different light fields present during the experiment. Another possibility unrelated to vision is that the up-regulation of 11-cis retinol dehydrogenase is related to nuclear retinoic acid receptor activation and transcription regulation (Ross 1993).

Metabolite transfer between host and endosymbiont

The transfer of metabolites between the coral host and Symbiodinium is at the core of this ecologically successful mutualism. The coral host provides Symbiodinium with glycine, ammonium, nitrate, sulfate, and guanine; Symbiodinium provides the coral host with glycolic acid, glycerol, glucose, alanine, lipids, and $\mathrm{CO}_{2}$; and both partners shuttle cystine, methionine, and cystathione back and forth (e.g. Muscatine 1967, Patton et al. 1977, Trench 1979, Papina et al. 2003). The down-regulation of the following protein transcripts suggests changes in the dynamics of transfer from host to endosymbiont: (1) multifunctional protein ADE2 (AOKF1956), involved in purine synthesis (Chen et al. 1990, Gavalas et al. 1993); (2) methylenetetrahydrofolate reductase (AOKF1692), involved in methionine synthesis (Yamada et al. 2005); and (3) a neutral and basic amino acid transporter (AOKF878), involved in the transport of cystine.

Conversely, the down-regulation of the following protein transcripts suggests changes in the dynamics of transfer from endosymbiont to host: (1) 1,4- $\alpha$ glucan-branching enzyme (AOKF1308), needed to increase the solubility of glycogen, the stored form of glucose; (2) glyceraldehyde-3-phosphate dehydrogenase (AOKG2283), responsible for transforming glycerol into glyceraldehyde-3-phosphate; and (3) vitellogenin-2 (CAOH1099), the major precursor of egg yolk proteins. The ortholog of vitellogenin-2 in Mon- tastraea faveolata (AOSF1022) was also down-regulated during bleaching (DeSalvo et al. 2008). While the activities of the first 2 genes listed above indicate the lack of exchange of glucose and glycerol from endosymbiont to host, suppressed host metabolism during thermal stress can also explain these observations. Additionally, the activity of vitellogenin-2 may also be due to less vitellogenesis in stressed corals, which is consistent with findings of lower reproduction in bleached corals (Ward et al. 2000). Lastly, the up-regulation of cAMP-dependent transcription factor ATF4 (CAOH936), which is responsive to amino acid starvation (Harding et al. 2003), supports the idea that the coral host loses the amino acid input from its endosymbionts during bleaching.

In addition to identifying genes involved in the transfer of metabolites, our results also indicate the presence of an alternative metabolic pathway in corals the glyoxylate cycle. Isocitrate lyase converts isocitrate to succinate and glyoxylate during the first step in the glyoxylate cycle. The glyoxylate cycle allows the use of fats to synthesize carbohydrates (Kornberg \& Madsen 1958). The pathway is present in bacteria, yeast, plants, nematodes, and has more recently been discovered in insects and vertebrates (Popov et al. 2005). The near 3-fold up-regulation of isocitrate lyase (AOKF 1837) at $2 \mathrm{~d}$ suggests that the host is not receiving sufficient carbohydrates from its endosymbionts. In addition to isocitrate lyase, malate synthase is another glyoxylate cycle-specific enzyme present in our EST libraries (CCHX12543.b1). Malate synthase catalyzes the transformation of glyoxylate and acetyl-coA into malate. Both malate synthase and isocitrate lyase are also present in the aposymbiotic larval transcriptome of Acropora millepora (Meyer et al. 2009), and phylogenetic analysis shows that both enzymes were acquired by cnidarians through horizontal gene transfer (Kondrashov et al. 2006).

\section{Nitric oxide signaling}

Perez \& Weis (2006) provide evidence that nitric oxide (NO) signaling is involved in the bleaching process. They showed that exogenous NO causes bleaching in Aiptasia pallida, and that oxidative stress triggers host production of NO. The hypothesized signaling events lead from ROS production to activation of NF- $\mathrm{BB}$, which causes up-regulation of inducible nitric oxide synthase (iNOS). NO then acts as a secondary messenger leading to cell death and thereby bleaching. While neither our EST libraries nor our microarray contains iNOS, our results support this hypothesized pathway given the strong up-regulation of NF- $\mathrm{KB}$ at both 1 and $2 \mathrm{~d}$ of stress. We targeted eNOS 
interacting protein (NOSIP, CCHX14559.b1) for qRTPCR analysis to further study NO signaling events during bleaching. NOSIP is a negative modulator of eNOS activity in vertebrates (Dedio et al. 2001); therefore, down-regulation of NOSIP indicates increased NO production. Indeed, our qRT-PCR results show a significant down-regulation of NOSIP transcripts in thermally stressed samples (Table 2). Lastly, the 2.2-fold up-regulation of HSP90 (AOKF986) at $1 \mathrm{~d}$ is noteworthy in the context of NO signaling since HSP90 is an allosteric enhancer of iNOS (Yoshida \& Xia 2003).

\section{Comparison with bleaching in Montastraea faveolata}

Our previous microarray study documented the transcriptomic response of Montastraea faveolata to thermal stress and bleaching (DeSalvo et al. 2008). Despite $<30 \%$ of the differentially expressed genes having functional annotation, we were able to corroborate past findings and provide new information regarding the cellular mechanisms of cnidarian bleaching. In the present study, differentially expressed genes were nearly $60 \%$ annotated. The gene overlap between the 2 microarray platforms is small ( 10\%) (Voolstra et al. 2009). Despite the low overlap and differences in the level of annotation between both microarrays, there are many parallels between the 2 studies. We identified the following transcriptomic responses in both studies: (1) an increase in heat shock protein (HSP) expression; (2) an increase in antioxidant enzymes; (3) a decrease in expression of $\mathrm{Ca}^{2+}$ homeostasis proteins; (4) a restructuring of the $\mathrm{ECM}_{i}(5)$ a rearrangement of the actin cytoskeleton; and (6) a decrease in ribosomal protein expression. In contrast, the following responses identified in the present study were not seen in $M$. faveolata: (1) osmotic stress; (2) p53 and NF-KB signaling; (3) sensory perception; (4) the glyoxylate cycle; and (5) nitric oxide signaling. Overall, the bleaching model presented in DeSalvo et al. (2008) is supported by the present study, and in addition, we have identified numerous other proteins (e.g. cell signaling molecules and ECM proteins) that await future functional work to assess their specific role in the coral-algal symbiosis.

A remarkable difference between the 2 studies (the present study and DeSalvo et al. 2008) is related to temporal patterns of bleaching. Given the same increase in temperature, Montastraea faveolata experienced a $60 \%$ reduction in Symbiodinium cell density after $9 \mathrm{~d}$. In the present study, Acropora palmata reached a $60 \%$ reduction in Symbiodinium cell density after only $2 \mathrm{~d}$. Thus, the intensity of stress felt by $A$. palmata was greater than that felt by $M$. faveolata. This could explain why fold change estimates in $A$. palmata were (on average) higher than those mea- sured in M. faveolata. This difference in bleaching susceptibility is consistent with previous studies showing that branching corals, especially acroporids, are more susceptible to bleaching compared to encrusting/ hemispherical corals (Harriott 1985, Glynn 1988, 1993, Hoeksema 1991, Gleason 1993, Hoegh-Guldberg \& Salvat 1995, Marshall \& Baird 2000, Loya et al. 2001). Loya et al. (2001) provide a sound discussion of likely differences between branching and encrusting colonies that underlie their differential bleaching susceptibilities. They found that massive and encrusting species have thicker tissue, which renders them less susceptible to bleaching because thicker tissue is more photoprotective and self-shading, especially when polyps are retracted (Brown 1997, Hoegh-Guldberg 1999). Another hypothesis posited by Loya et al. (2001) involves differential mass transfer. These ideas are discussed further in Nakamura \& van Woesik (2001) and hold that high water flow allows more efficient transfer of mass (i.e. metabolites, and ROS), which is especially needed during stress. Indeed, higher coral survival was evident in high- compared to low-flow regimes (Nakamura et al. 2003). These notions ultimately apply to colony morphology; flat, encrusting coral colonies experience higher flow than branching colonies.

While bleaching susceptibility due to colony morphology is likely involved in the observed differential response between Montastraea faveolata and Acropora palmata, we also cannot ignore the influence of Symbiodinium genotype (Rowan et al. 1997, Baker et al. 2004, LaJeunesse et al. 2007, Sampayo et al. 2008). Given that we observed no differences in bleaching susceptibility between clade A-associated and multiclade-associated M. faveolata (DeSalvo et al. 2008), and that subclade genotyping to differentiate between clade A within $M$. faveolata and clade A within $A$. palmata is not available, we cannot state whether a Symbiodinium clade effect influenced the differential response between M. faveolata and A. palmata. Differences in Symbiodinium clades might also contribute to the greater fold changes measured in A. palmata. Since the effect of the Symbiodinium clade on the host transcriptome can be greater than that of thermal stress (DeSalvo et al. 2010), controlling for the Symbiodinium clade content within experimental fragments is likely to increase the resolution at which gene expression can be measured.

\section{CONCLUSIONS}

Despite little overlap between the Acropora palmata and Montastraea faveolata microarrays, we found similar processes that are differentially expressed in response to thermal stress and bleaching in both spe- 
cies. Much of this conserved transcriptomic stress response is part of the cellular stress response that was already present in the last universal common ancestor (i.e. predating the evolution of the 3 domains of life; Kultz 2003, 2005).

Focusing on the cellular stress response and how it has allowed corals to persist through geologic time is incomplete without taking into consideration the contribution of their endosymbionts in the evolutionary success of the Scleractinia. For example, the adaptive radiation of scleractinians in the Late Triassic (200$228 \mathrm{Ma}$ ) may be correlated with the initiation of symbiosis with dinoflagellate endosymbionts (Stanley 1981). Thus, it is also important to identify scleractinian- and symbiosis-specific cellular responses to thermal stress. For example, while down-regulation of cytoskeletal components (also seen in Montastraea faveolata) is certainly related to the conserved cellular stress response (Loven 1988, Shyy et al. 1989, Chowdhury et al. 1992, Orrenius et al. 1992, Muller et al. 2007), we cannot ignore the possibility that the cytoskeleton must reorganize as cells change their adhesion properties and/or become devoid of their intracellular endosymbionts. Likewise, a rearrangement of the ECM (also seen in M. faveolata), along with the metabolite transfer systems, which involve molecules specific to different symbioses (Trench 1979), are also likely to be bleaching responses specific to zooxanthellate corals.

Identifying responses that are specific to symbiosis breakdown is a daunting task. Future transcriptomic studies using stressors other than temperature (e.g. cold shock, darkness, high light) in corals and other symbiotic cnidarians will allow us to identify cellular processes that are common among different stressors. Utilizing the amenable symbiotic cnidarian Aiptasia pallida (Weis et al. 2008, Sunagawa et al. 2009), one could measure the transcriptomic response to a given stressor in both symbiotic and aposymbiotic anemones, and thus use a subtractive approach to determining symbiosis-specific stress responses. These experimental approaches will ultimately lead to a more complete understanding of the molecular mechanisms of coral symbiosis and bleaching.

Finally, our study demonstrates how genomic tools are helping to reconstruct the ancestral coral and how it was equipped to cope with stress over geologic time. For example, early scleractinian corals survived many paleoclimatic changes, such as sea-level rise and climatic warming in the Late Triassic, the PaleoceneEocene thermal maximum, and repeated sea-level and climatic changes during the Neogene (Stanley \& van de Schootbrugge 2009). The resilience of coral community structure during global climate fluctuations of the Pleistocene (Pandolfi \& Jackson 2006) also suggests that corals are equipped to survive drastic environmental transitions. While the resiliency of corals over geologic time suggests that they may indeed be able to cope with thermal stress related to contemporary climate change, it is becoming abundantly clear that numerous other human impacts are acting synergistically with climate change to shift coral community structure (Hughes et al. 2003, Pandolfi et al. 2003, Pandolfi \& Jackson 2006).

Acknowledgements. We thank the following people associated with STRI in Panamá: R. Collin, G. Jácome, P. Gondola and other staff at the Bocas del Toro station, and E. Gomez and J. Jara of N. Knowlton's laboratory at the Naos Laboratory. We also thank M. A. Coffroth for initial input with tank experiments, and 3 anonymous reviewers whose comments greatly improved the manuscript. M.D. prepared this manuscript in partial fulfillment of requirements for a $\mathrm{PhD}$ in Quantitative and Systems Biology from the University of California, Merced. This study was supported through an STRI Pre-doctoral Fellowship and an NSF award to M.D. (OISE 0837455), and NSF awards to M.M. (BE-GEN 0313708 and IOS 0644438). This is contribution \#2 of the STRI Caribbean Reef Futures initiative.

\section{LITERATURE CITED}

Baker AC, Rowan R, Knowlton N (1997) Symbiosis ecology of two Caribbean Acroporid corals. Proc 8th Int Coral Reef Symp Panama City 2:1295-1300

Baker AC, Starger CJ, McClanahan TR, Glynn PW (2004) Coral reefs: corals' adaptive response to climate change. Nature 430:741

Bell J, Neilson L, Pellegrini M (1988) Effect of heat shock on ribosome synthesis in Drosophila melanogaster. Mol Cell Biol 8:91-95

Boatright KM, Salvesen GS (2003) Mechanisms of caspase activation. Curr Opin Cell Biol 15:725-731

Brown BE (1997) Adaptations of reef corals to physical environmental stress. Adv Mar Biol 31:221-299

Buckley BA, Gracey AY, Somero GN (2006) The cellular response to heat stress in the goby Gillichthys mirabilis: a cDNA microarray and protein-level analysis. J Exp Biol 209:2660-2677

Cheah KS, Lau ET, Au PK, Tam PP (1991) Expression of the mouse alpha 1(II) collagen gene is not restricted to cartilage during development. Development 111:945-953

Chen ZD, Dixon JE, Zalkin H (1990) Cloning of a chicken liver cDNA encoding 5-aminoimidazole ribonucleotide carboxylase and 5-aminoimidazole-4-N-succinocarboxamide ribonucleotide synthetase by functional complementation of Escherichia coli pur mutants. Proc Natl Acad Sci USA 87:3097-3101

Chowdhury S, Smith KW, Gustin MC (1992) Osmotic stress and the yeast cytoskeleton: phenotype-specific suppression of an actin mutation. J Cell Biol 118:561-571

Clem RJ, Cheng EH, Karp CL, Kirsch DG and others (1998) Modulation of cell death by Bcl-XL through caspase interaction. Proc Natl Acad Sci USA 95:554-559

> Dedio J, Konig P, Wohlfart P, Schroeder C, Kummer W, Muller-Esterl W (2001) NOSIP, a novel modulator of endothelial nitric oxide synthase activity. FASEB J 15:79-89

- DeSalvo MK, Voolstra CR, Sunagawa S, Schwarz JA and others (2008) Differential gene expression during thermal 
stress and bleaching in the Caribbean coral Montastraea faveolata. Mol Ecol 17:3952-3971

DeSalvo MK, Sunagawa S, Fisher PL, Voolstra CR, IglesiasPrieto R, Medina M (2010) Coral host transcriptomic states are correlated with Symbiodinium genotypes. Mol Ecol 19:1174-1186

$>$ Downs CA, Mueller E, Phillips S, Fauth JE, Woodley CM (2000) A molecular biomarker system for assessing the health of coral (Montastraea faveolata) during heat stress. Mar Biotechnol 2:533-544

Downs CA, Fauth JE, Halas JC, Dustan P, Bemiss J, Woodley CM (2002) Oxidative stress and seasonal coral bleaching. Free Radic Biol Med 33:533-543

> Downs CA, Fauth JE, Robinson CE, Curry R and others (2005) Cellular diagnostics and coral health: declining coral health in the Florida Keys. Mar Pollut Bull 51:558-569

Downs CA, Kramarsky-Winter E, Martinez J, Kushmaro A, Woodley CM, Loya Y, Ostrander GK (2009) Symbiophagy as a cellular mechanism for coral bleaching. Autophagy 5: 211-216

- Dunn SR, Schnitzler CE, Weis VM (2007) Apoptosis and autophagy as mechanisms of dinoflagellate symbiont release during cnidarian bleaching: every which way you lose. Proc Biol Sci 274:3079-3085

Dykens JA, Shick JM, Benoit C, Buettner GR, Winston GW (1992) Oxygen radical production in the sea anemone Anthopleura elegantissima and its endosymbiotic algae. J Exp Biol 168:219-241

Edge SE, Morgan MB, Gleason DF, Snell TW (2005) Development of a coral cDNA array to examine gene expression profiles in Montastraea faveolata exposed to environmental stress. Mar Pollut Bull 51:507-523

Edge SE, Morgan MB, Snell TW (2008) Temporal analysis of gene expression in a field population of the scleractinian coral Montastraea faveolata. J Exp Mar Biol Ecol 355: 114-124

Gates RD, Edmunds PJ (1999) The physiological mechanisms of acclimatization in tropical reef corals. Am Zool 39: 30-43

> Gates RD, Baghdasarian G, Muscatine L (1992) Temperature stress causes host cell detachment in symbiotic cnidarians: implications for coral bleaching. Biol Bull 182:324-332

> Gavalas A, Dixon JE, Brayton KA, Zalkin H (1993) Coexpression of two closely linked avian genes for purine nucleotide synthesis from a bidirectional promoter. Mol Cell Biol 13:4784-4792

Gleason MG (1993) Effects of disturbance on coral communities: bleaching in Moorea, French Polynesia. Coral Reefs 12:193-201

Glynn PW (1988) El-Nino Southern Oscillation 1982-1983: nearshore population, community, and ecosystem responses. Annu Rev Ecol Syst 19:309-345

> Glynn PW (1993) Coral reef bleaching: ecological perspectives. Coral Reefs 12:1-17

> Gracey AY, Troll JV, Somero GN (2001) Hypoxia-induced gene expression profiling in the euryoxic fish Gillichthys mirabilis. Proc Natl Acad Sci USA 98:1993-1998

Grasso LC, Maindonald J, Rudd S, Hayward DC, Saint R, Miller DJ, Ball EE (2008) Microarray analysis identifies candidate genes for key roles in coral development. BMC Genomics 9:540

> Harding HP, Zhang Y, Zeng H, Novoa I and others (2003) An integrated stress response regulates amino acid metabolism and resistance to oxidative stress. Mol Cell 11:619-633

Harriott VJ (1985) Mortality rates of scleractinian corals before and during a mass bleaching event. Mar Ecol Prog Ser 21:81-88
Helman Y, Natale F, Sherrell RM, Lavigne M, Starovoytov V, Gorbunov MY, Falkowski PG (2008) Extracellular matrix production and calcium carbonate precipitation by coral cells in vitro. Proc Natl Acad Sci USA 105:54-58

> Herruer MH, Mager WH, Raue HA, Vreken P, Wilms E, Planta RJ (1988) Mild temperature shock affects transcription of yeast ribosomal protein genes as well as the stability of their mRNAs. Nucleic Acids Res 16:7917-7929

> Hockenbery D, Nunez G, Milliman C, Schreiber RD, Korsmeyer SJ (1990) Bcl-2 is an inner mitochondrial membrane protein that blocks programmed cell death. Nature 348 : 334-336

> Hoegh-Guldberg O (1999) Climate change, coral bleaching and the future of the world's coral reefs. Mar Freshw Res 50:839-866

> Hoegh-Guldberg O, Salvat B (1995) Periodic mass-bleaching and elevated sea temperatures: bleaching of outer reef slope communities in Moorea, French Polynesia. Mar Ecol Prog Ser 121:181-190

> Hoegh-Guldberg O, Mumby PJ, Hooten AJ, Steneck RS and others (2007) Coral reefs under rapid climate change and ocean acidification. Science 318:1737-1742

> Hoeksema BW (1991) Control of bleaching in mushroom coral populations (Scleractinia: Fungiidae) in the Java Sea: stress tolerance and interference by life history strategy. Mar Ecol Prog Ser 74:225-237

> Hughes TP, Baird AH, Bellwood DR, Card M and others (2003) Climate change, human impacts, and the resilience of coral reefs. Science 301:929-933

Jones RJ, Hoegh-Guldberg O, Larkum AWD, Schreiber U (1998) Temperature-induced bleaching of corals begins with impairment of the $\mathrm{CO}_{2}$ fixation mechanism in zooxanthellae. Plant Cell Environ 21:1219-1230

Katzenellenbogen RA, Egelkrout EM, Vliet-Gregg P, Gewin LC, Gafken PR, Galloway DA (2007) NFX1-123 and poly(A) binding proteins synergistically augment activation of telomerase in human papillomavirus type 16 E6expressing cells. J Virol 81:3786-3796

> Kondrashov FA, Koonin EV, Morgunov IG, Finogenova TV, Kondrashova MN (2006) Evolution of glyoxylate cycle enzymes in Metazoa: evidence of multiple horizontal transfer events and pseudogene formation. Biol Direct 1:31

> Kornberg HL, Madsen NB (1958) The metabolism of C2 compounds in microorganisms. 3. Synthesis of malate from acetate via the glyoxylate cycle. Biochem J 68:549-557

- Kozmik Z, Ruzickova J, Jonasova K, Matsumoto Y and others (2008) Assembly of the cnidarian camera-type eye from vertebrate-like components. Proc Natl Acad Sci USA 105: 8989-8993

Kultz D (2003) Evolution of the cellular stress proteome: from monophyletic origin to ubiquitous function. J Exp Biol 206: 3119-3124

Kultz D (2005) Molecular and evolutionary basis of the cellular stress response. Annu Rev Physiol 67:225-257

Kultz D, Madhany S, Burg MB (1998) Hyperosmolality causes growth arrest of murine kidney cells. Induction of GADD45 and GADD153 by osmosensing via stress-activated protein kinase 2. J Biol Chem 273:13645-13651

> LaJeunesse TC, Reyes-Bonilla H, Warner ME (2007) Spring 'bleaching' among Pocillopora in the Sea of Cortez, Eastern Pacific. Coral Reefs 26:265-270

Lesser MP (1997) Oxidative stress causes coral bleaching during exposure to elevated temperatures. Coral Reefs 16: $187-192$

> Lesser MP (2006) Oxidative stress in marine environments: biochemistry and physiological ecology. Annu Rev Physiol 68:253-278 
Lesser MP, Farrell JH (2004) Exposure to solar radiation increases damage to both host tissues and algal symbionts of corals during thermal stress. Coral Reefs 23:367-377

Li SW, Prockop DJ, Helminen H, Fassler R and others (1995) Transgenic mice with targeted inactivation of the Col2 alpha 1 gene for collagen II develop a skeleton with membranous and periosteal bone but no endochondral bone. Genes Dev 9:2821-2830

Loven DP (1988) A role for reduced oxygen species in heat induced cell killing and the induction of thermotolerance. Med Hypotheses 26:39-50

- Loya Y, Sakai K, Yamazato K, Nakano Y, Sambali H, van Woesik R (2001) Coral bleaching: the winners and the losers. Ecol Lett 4:122-131

Marshall PA, Baird AH (2000) Bleaching of corals on the Great Barrier Reef: differential susceptibilities among taxa. Coral Reefs 19:155-163

Mayfield AB, Gates RD (2007) Osmoregulation in anthozoan-dinoflagellate symbiosis. Comp Biochem Physiol A Mol Integr Physiol 147:1-10

Medina M, Collins AG, Takaoka TL, Kuehl JV, Boore JL (2006) Naked corals: skeleton loss in Scleractinia. Proc Natl Acad Sci USA 103:9096-9100

Meyer E, Aglyamova GV, Wang S, Buchanan-Carter J and others (2009) Sequencing and de novo analysis of a coral larval transcriptome using 454 GS-Flx. BMC Genomics 10:219

Mizushima N, Sugita H, Yoshimori T, Ohsumi Y (1998) A new protein conjugation system in human. The counterpart of the yeast Apg12p conjugation system essential for autophagy. J Biol Chem 273:33889-33892

Morgan MB, Edge SE, Snell TW (2005) Profiling differential gene expression of corals along a transect of waters adjacent to the Bermuda municipal dump. Mar Pollut Bull 51: 524-533

Muller J, Menzel D, Samaj J (2007) Cell-type specific disruption and recovery of the cytoskeleton in Arabidopsis thaliana epidermal root cells upon heat shock stress. Protoplasma 230:231-242

> Muscatine L (1967) Glycerol excretion by symbiotic algae from corals and Tridacna and its control by the host. Science 156:516-519

Nakamura T, van Woesik R (2001) Water-flow rates and passive diffusion partially explain differential survival of corals during the 1998 bleaching event. Mar Ecol Prog Ser 212:301-304

- Nakamura T, Yamasaki H, van Woesik R (2003) Water flow facilitates recovery from bleaching in the coral Stylophora pistillata. Mar Ecol Prog Ser 256:287-291

Nii CM, Muscatine L (1997) Oxidative stress in the symbiotic sea anemone Aiptasia pulchella (Carlgren, 1943): contribution of the animal to superoxide ion production at elevated temperature. Biol Bull 192:444-456

> Orrenius S, Burkitt MJ, Kass GE, Dypbukt JM, Nicotera P (1992) Calcium ions and oxidative cell injury. Ann Neurol 32(Suppl):S33-S42

Pandolfi JM, Jackson JB (2006) Ecological persistence interrupted in Caribbean coral reefs. Ecol Lett 9:818-826

Pandolfi JM, Bradbury RH, Sala E, Hughes TP and others (2003) Global trajectories of the long-term decline of coral reef ecosystems. Science 301:955-958

Papina M, Meziane T, van Woesik R (2003) Symbiotic zooxanthellae provide the host-coral Montipora digitata with polyunsaturated fatty acids. Comp Biochem Physiol B Biochem Mol Biol 135:533-537

Park WR, Nakamura Y (2005) p53CSV, a novel p53-inducible gene involved in the p53-dependent cell-survival pathway. Cancer Res 65:1197-1206
Patton JS, Abraham S, Benson AA (1977) Lipogenesis in the intact coral Pocillopora capitata and its isolated zooxanthellae: evidence for a light-driven carbon cycle between symbiont and host. Mar Biol 44:235-247

> Pereira SG, Oakley F (2008) Nuclear factor-kappaB1: regulation and function. Int J Biochem Cell Biol 40:1425-1430

> Perez S, Weis V (2006) Nitric oxide and cnidarian bleaching: an eviction notice mediates breakdown of a symbiosis. J Exp Biol 209:2804-2810

Perkins ND (2007) Integrating cell-signalling pathways with NF-kappaB and IKK function. Nat Rev Mol Cell Biol 8: 49-62

Popov VN, Moskalev EA, Shevchenko M, Eprintsev AT (2005) Comparative analysis of the glyoxylate cycle clue enzyme isocitrate lyases from organisms of different systemic groups. Zh Evol Biokhim Fiziol 41:507-513

Prives C, Hall PA (1999) The p53 pathway. J Pathol 187: $112-126$

Richier S, Rodriguez-Lanetty M, Schnitzler CE, Weis VM (2008) Response of the symbiotic cnidarian Anthopleura elegantissima transcriptome to temperature and UV increase. Comp Biochem Physiol D Genomics Proteomics 3:283-289

- Rodriguez-Lanetty M, Phillips WS, Weis VM (2006) Transcriptome analysis of a cnidarian-dinoflagellate mutualism reveals complex modulation of host gene expression. BMC Genomics 7:23

Rodriguez-Lanetty M, Phillips WS, Dove S, Hoegh-Guldberg O, Weis VM (2008) Analytical approach for selecting normalizing genes from a cDNA microarray platform to be used in q-RT-PCR assays: a cnidarian case study. J Biochem Biophys Methods 70:985-991

> Ross AC (1993) Cellular metabolism and activation of retinoids: roles of cellular retinoid-binding proteins. FASEB J 7:317-327

Rowan R, Knowlton N (1995) Intraspecific diversity and ecological zonation in coral-algal symbiosis. Proc Natl Acad Sci USA 92:2850-2853

> Rowan R, Powers DA (1991) Molecular genetic identification of symbiotic dinoflagellates (zooxanthellae). Mar Ecol Prog Ser 71:65-73

> Rowan R, Knowlton N, Baker AC, Jara J (1997) Landscape ecology of algal symbiont communities explains variation in episodes of coral bleaching. Nature 388:265-269

Saeed AI, Sharov V, White J, Li J and others (2003) TM4: a free, open-source system for microarray data management and analysis. Biotechniques 34:374-378

Sampayo EM, Ridgway T, Bongaerts P, Hoegh-Guldberg O (2008) Bleaching susceptibility and mortality of corals are determined by fine-scale differences in symbiont type. Proc Natl Acad Sci USA 105:10444-10449

Santillo S, Orlando P, De Petrocellis L, Cristino L, Guglielmotti V, Musio C (2006) Evolving visual pigments: hints from the opsin-based proteins in a phylogenetically old 'eyeless' invertebrate. Biosystems 86:3-17

- Schwarz JA, Brokstein PB, Voolstra C, Terry AY and others (2008) Coral life history and symbiosis: functional genomic resources for two reef building Caribbean corals, Acropora palmata and Montastraea faveolata. BMC Genomics 9:97

Scott IC, Blitz IL, Pappano WN, Imamura Y and others (1999) Mammalian BMP-1/Tolloid-related metalloproteinases, including novel family member mammalian Tolloid-like 2, have differential enzymatic activities and distributions of expression relevant to patterning and skeletogenesis. Dev Biol 213:283-300

Shimizu S, Eguchi Y, Kamiike W, Matsuda H, Tsujimoto Y (1996) Bcl-2 expression prevents activation of the ICE protease cascade. Oncogene 12:2251-2257 
Shyy TT, Asch BB, Asch HL (1989) Concurrent collapse of keratin filaments, aggregation of organelles, and inhibition of protein synthesis during the heat shock response in mammary epithelial cells. J Cell Biol 108:997-1008

Stanley GD (1981) The early history of scleractinian corals and its geologic consequences. Geology 9:507-511

Stanley GD, van de Schootbrugge B (2009) The evolution of the coral-algal symbiosis. In: van Oppen MJH, Lough JM (eds) Coral bleaching: patterns, processes, causes and consequences, Vol 205. Spinger Verlag, Berlin

Sullivan JC, Kalaitzidis D, Gilmore TD, Finnerty JR (2007) Rel homology domain-containing transcription factors in the cnidarian Nematostella vectensis. Dev Genes Evol 217: 63-72

Sunagawa S, Wilson EC, Thaler M, Smith ML and others (2009) Generation and analysis of transcriptomic resources for a model system on the rise: the sea anemone Aiptasia pallida and its dinoflagellate endosymbiont. BMC Genomics 10:258

Tibshirani R, Hastie T, Narasimhan B, Chu G (2002) Diagnosis of multiple cancer types by shunken centroids of gene expression. Proc Natl Acad Sci USA 99:6567-6572

Townsend JP, Hartl DL (2002) Bayesian analysis of gene expression levels: statistical quantification of relative mRNA level across multiple strains or treatments. Genome Biol 3:research0071.0071-0071.0016

Trench RK (1979) The cell biology of plant-animal symbiosis. Annu Rev Plant Physiol 30:485-531

> Vandesompele J, De Preter K, Pattyn F, Poppe B, Van Roy N, De Paepe A, Speleman F (2002) Accurate normalization of

Editorial responsibility: Gretchen Hofmann, Santa Barbara, California, USA real-time quantitative RT-PCR data by geometric averaging of multiple internal control genes. Genome Biol 3: research0034.1-0034.11

> Vargas MR, Pehar M, Cassina P, Beckman JS, Barbeito L (2006) Increased glutathione biosynthesis by Nrf2 activation in astrocytes prevents p75NTR-dependent motor neuron apoptosis. J Neurochem 97:687-696

Voolstra CR, Schwarz JA, Schnetzer J, Sunagawa S and others (2009) The host transcriptome remains unaltered during the establishment of coral-algal symbioses. Mol Ecol 18:1823-1833

Ward S, Harrison P, Hoegh-Guldberg O (2000) Coral bleaching reduces reproduction of scleractinian corals and increases susceptibility to future stress. Proc 9th Int Coral Reef Symp Bali 2:1123-1128

> Weis VM (2008) Cellular mechanisms of cnidarian bleaching: stress causes the collapse of symbiosis. J Exp Biol 211: 3059-3066

Weis VM, Davy SK, Hoegh-Guldberg O, Rodriguez-Lanetty M, Pringle JR (2008) Cell biology in model systems as the key to understanding corals. Trends Ecol Evol 23:369-376

> Yamada K, Strahler JR, Andrews PC, Matthews RG (2005) Regulation of human methylenetetrahydrofolate reductase by phosphorylation. Proc Natl Acad Sci USA 102:10454-10459

> Yoshida M, Xia Y (2003) Heat shock protein 90 as an endogenous protein enhancer of inducible nitric-oxide synthase. J Biol Chem 278:36953-36958

Zheng Q, Wang XJ (2008) GOEAST: a web-based software toolkit for gene ontology enrichment analysis. Nucleic Acids Res 36:W358-W363

Submitted: June 12, 2009; Accepted: October 13, 2009

Proofs received from author(s): February 16, 2010 